Received 25.04.2016 Reviewed 27.05.2016 Accepted 13.06.2016

A - study design

B - data collection

C - statistical analysis

D - data interpretation

E - manuscript preparation

F - literature search

\section{Drought intensity and spatial variability in Gabes Watershed, south-eastern Tunisia}

\author{
Sabrine JEMAI ${ }^{1)}$ ABCDEF, Manel ELLOUZE ${ }^{1) ~ A B C D E F, ~}$ \\ Belgacem AGOUBI ${ }^{2)}$ ABCDEF , Habib ABIDA ${ }^{\text {1) ABCDEF }}$
}

\footnotetext{
${ }^{1)}$ Faculty of Sciences of Sfax, Road Sokra, 3000 Sfax, Tunisia, e-mail: jemai.sabrine@gmail.com, manel.ellouze@hotmail.com, habibabida62@gmail.com

${ }^{2)}$ Higher Institute of Water Sciences and Techniques of Gabes, Tunisia, e-mail: belgacem.agoubi@isstegb.rnu.tn
}

\begin{abstract}
For citation: Jemai S., Ellouze M., Agoubi B., Abida H. 2016. Drought intensity and spatial variability in Gabes Watershed, south-eastern Tunisia. Journal of Water and Land Development. No. 31 p. 63-72. DOI: 10.1515/jwld2016-0037.
\end{abstract}

\begin{abstract}
Chronological series of monthly and annual precipitation data recorded in Gabes Watershed, south-eastern Tunisia, were analyzed. The study is based on the standardized precipitation index (SPI) values, computed for 10 rainfall stations over the period 1987-2012, which corresponds to an observatory period of 25 hydrologic years (from September to August). The results obtained show a great variability in SPI values. The historical evolution of the SPI made it possible to define the periods of excess and deficit, corresponding to wet and dry periods respectively. The wet years were found to be 1989-1990, 1995-1996 and 2006-2007 while the dry years were 1987-1988, 1996-1997, 2000-2001, 2001-2002, 2007-2008, 2008-2009 and 2009-2010. This clearly shows alternating wet and dry periods, but with drought episodes taking prevalence over rainy fronts throughout the study period. Indeed, a high tendency towards a drop in precipitation and important sequences of drought were observed. Spatial variability of drought throughout Gabes Watershed was examined by geostatistical analysis of $S P I$, as drought and rainfall distribution vary with latitude, longitude, topography and proximity to the Mediterranean Sea. The results obtained showed that, compared to coastal and southern areas, drought was observed to be more important in the West and the North of Gabes Watershed. The SPI showed that moderate droughts are generally more frequent than severe or extreme droughts in most of the Watershed.
\end{abstract}

Key words: drought, geostatistics, precipitation, standardized precipitation index, trend analysis, Tunisia

\section{INTRODUCTION}

Drought is an extreme hydrological process which may have serious economic and social consequences, mainly on agriculture and health. According to the Intergovernmental Panel on climate change assessment report, more and more regions of the world were affected by drought problems since the 70s [IPCC 2007]. Drought can be referred to as a normal recurring feature of the Earth's climate; it has a peculiar slow onset and disastrous long lasting impacts; it affects more people than any other form of natural disaster. It is characterized by its spatial extension; intensity and duration. Several indices characterizing droughts are available in the literature, such as decile index (DI) [GIBBS, MAHER 1967], percent of normal (PN) [WILLEKE et al. 1994], Palmer drought severity index (PDSI) [PALMER 1965], crop moisture index CMI [PALMER 1968], surface water supply index (SWSI) [SHAFER, DEZMAN 1982]. However, the most widely used and commonly accepted drought index is the standardized precipitation index $(S P I)$. The SPI, developed in Colorado University by MCKEE et al. [1993], characterizes precipitation defi- 
cits for a given period. It allows comparison between stations having different precipitation amounts and different climatic characteristics.

Precipitation is one of the most important meteorological variables which can impact the occurrence of drought or flood. Analysis of precipitation and drought data yields important information, used to improve water management strategies, protect the environment, plan agricultural production or, in general, impact economic development of a certain region [Gocic, TRAJKOVIC 2013]. Many studies examined temporal and spatial viability of rainfall, especially based on statistical methods. These include studies by GONG et al. [2004], MODARRES and Silva [2007], ELlOUZE et al. [2009], AMRUTHA and SHREEDHAR [2014] among others. In particular, many studies examined rainfall trends in arid and semi-arid regions all over the world. SILVA [2004] analyzed climate variability, especially temporal trends, in the North east of Brazil. GONG et al. [2004] analyzed many aspects of the daily rainfall characteristics, such as the number of rainy days, precipitation intensity and maximum daily rainfall of 30 stations in the semi-arid region of northern China to study the climate variation. This study showed that there are significant secular trends in some aspects of the daily rains in Northern China, especially in the warm season. Meanwhile, the light rain shows significant trends towards stronger intensity. Moreover, global warming and human-induced land cover changes are expected to be related to changes in precipitation. In the same context, MoDARRES and SILVA [2007] used the time series of annual and monthly rainfall of 20 rainfall stations to assess climate variability in the arid region of Iran. ELLOUZE et al. [2009] studied rainfall variability in Southern Tunisia based on monthly and annual rainfall data collected from 12 stations. The results obtained showed the influence of topography and seasonality on rainfall distribution. BĄK and LABĘDZKI [2014] analyzed the occurrence of precipitation deficit and excess in the growing seasons in Bydgoszcz region. Obtained scenario of the distribution of precipitation deficits and excesses and forecast trends of monthly sums of precipitation suggest, that meteorological, agricultural and hydrological drought will still present problems in agricultural production and water availability in Bydgoszcz region. The number of months and longer periods with drought will increase starting from the 2020s. LABĘDZKI [2016] characterized the phenomena of droughts and water scarcity in Polish agriculture and their impacts on crop yield to improve the uniform national plans of drought and to release recommendations stating the most adequate measures to be undertaken.

Spatial variability of hydrologic variables can be mapped using different interpolation techniques, available in the literature. Missing hydrological data may also be estimated based on spatial interpolation algorithms. These latter can be classified into two categories: the deterministic methods such as inverse- -distance weighting and non-linear interpolation spline techniques, and the stochastic interpolation methods of the kriging family, such as simple kriging, ordinary kriging, and universal kriging [HALL, BARCLAY 1975]. Kriging is a statistical tool used to simulate spatial variability of different variables, known at discrete points of a continuous field or domain. It has been applied recently in few cases to map precipitation fields [DELFINER, DELHOMME 1975; FEKI et al. 2012].

The present study examines temporal and spatial variability of rainfall, at different scales (annual and monthly), over the period 1987-2012, in Gabes Watershed (southern Tunisia), where rainfall is characterized by its shortage and erratic distribution in both time and space. Standard precipitation index $(S P I)$ is first computed for 10 rainfall stations, evenly distributed over the study basin, and extreme rainfall events are selected. Next, SPI spatial variability for the selected extreme events is simulated using kriging techniques, implying the identification of the extent and the severity of the drought episodes that hit the watershed over the study period.

Following this brief introduction, the paper first presents the study area, the data used and the adopted methodology in section 2. Section 3 is devoted to the presentation and discussion of the results obtained. Finally, conclusions and recommendations are presented in section 4 .

\section{MATERIALS AND METHODS}

\section{STUDY AREA AND DATA USED}

Gabes Watershed, located in southern Tunisia, extends over an area of $3125 \mathrm{~km}^{2}$ (Fig. 1a). It is located between $9^{\circ} \mathrm{E}$ and $10^{\circ} \mathrm{E}$ in longitude and $33^{\circ} \mathrm{N}$ to $34^{\circ} \mathrm{N}$ in latitude. Figure $1 \mathrm{~b}$ shows the Digital Elevation Model of the watershed, characterized mainly by mild topography, with altitudes varying from 4 to 600 $\mathrm{m}$. The exception is made for the mountainous region of Matamata in the South, where altitudes vary from 120 to $610 \mathrm{~m}$. On the other hand, low zones include humid spots (Sebkhas and Chotts), representing the natural outlets of many intermittent streams called wadis. The study basin is subjected to a Mediterranean climate, belonging to the arid bioclimatic stage, characterized by mild wet winters and hot and dry summers [ELLOUZE et al. 2009]. It is subjected, by its position, to two types of climatic influences: the Sahara in the South and the Mediterranean Sea in the East. In summer, it is the first type of influence that dominates as the Sahara is subjected to cyclonic conditions that go well beyond Tunisia.

The average annual temperature varies between 18 and $20^{\circ} \mathrm{C}$. The average annual evaporation ranges between 1500 and $2000 \mathrm{~mm}$. Most of the winds of the year are generally of eastern and north-eastern directions. Winds from the South and South-West, with average velocities exceeding $5 \mathrm{~m} \cdot \mathrm{s}^{-1}$, are usually dry and generate sand storms. 


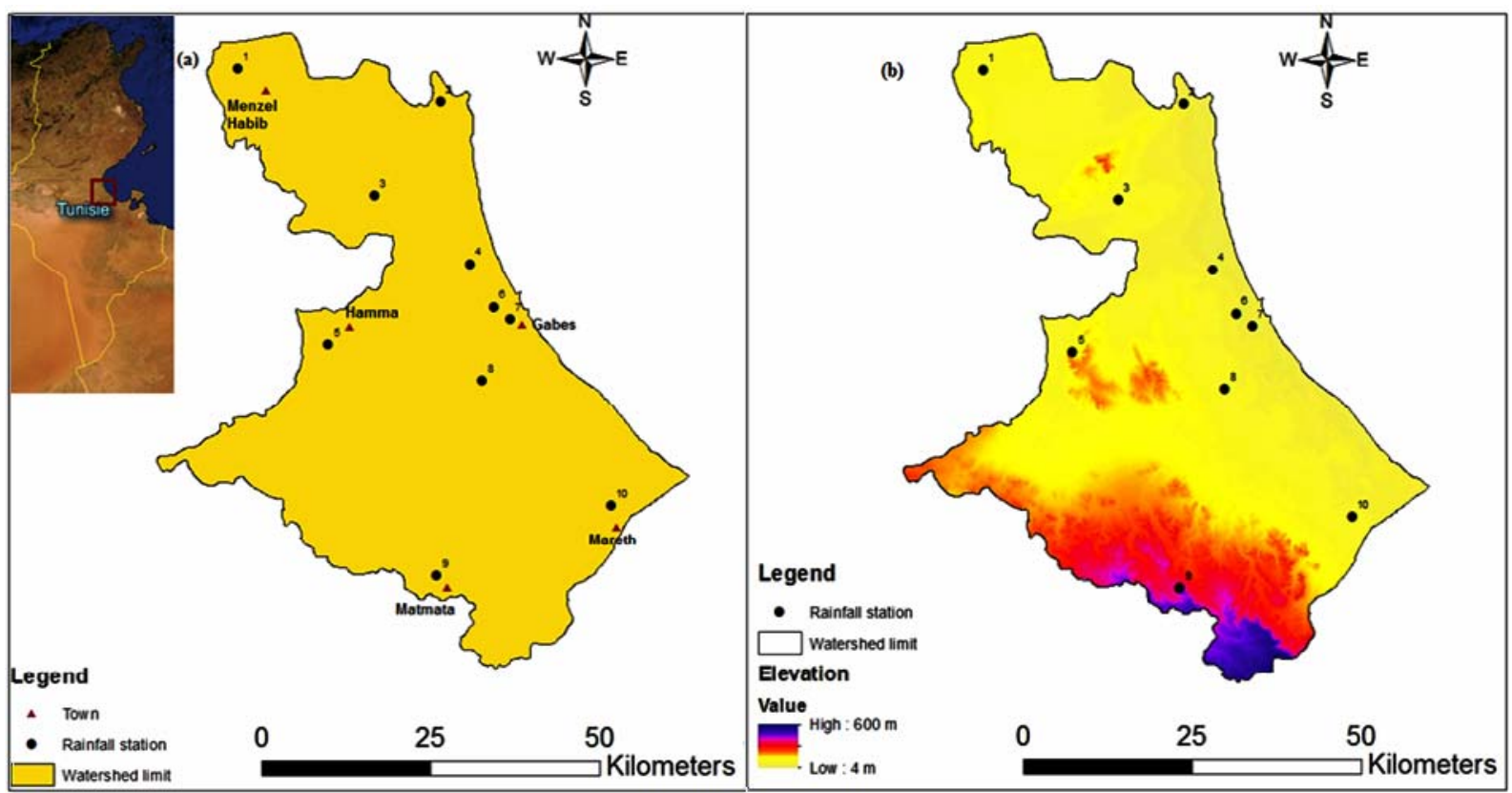

Fig. 1. (a) Geographical situation and distribution of rainfall stations in Gabes Watershed; (b) Digital Elevation Model of Gabes Watershed; source: own elaboration

Rainfall throughout Gabes Basin is characterized by its scarcity and erratic distribution, with intense rainfall events, resulting in flash floods. The mean annual rainfall over the study area is about $158 \mathrm{~mm}$, ranging between more than $200 \mathrm{~mm}$, in the coastal sector and less than $90 \mathrm{~mm}$, in the North West [ELLOUZE et al. 2009]. As to annual variability, annual rainfall in Gabes Station, for instance, varied from $57 \mathrm{~mm}$ in 2012 to $552 \mathrm{~mm}$ in 1995, implying a ratio of 10 between maximum and minimum annual rainfall.

Series of annual and monthly precipitation data were collected at 10 rainfall stations spread all over Gabes Watershed during the period 1987-2012 (Fig. 1a), where hydrologic years (from September to August) were considered. The precipitation data sets were provided by the Tunisian Ministry of Agriculture and Water Resources publications. The selected date sets are characterized by a minimum chronological period of 25 years and the corresponding stations are fairly evenly spread throughout the study region. The geographical characteristics of the selected rainfall stations are given in Table 1. Most of the stations are located along the coast with altitudes, not exceeding $100 \mathrm{~m}$. The exception is made for station 9, where the altitude is $441 \mathrm{~m}$. This latter is located in the mountains region of Matmata in the South of the study basin. The precipitation data sets were first investigated for randomness, homogeneity and absence of trends by using the test of Mann-Kendall [GILBERT 1987; KendALL 1975; MANN 1945]. All stations passed the test with a confidence interval of $95 \%$.
Table 1. Geographical characteristics of the rainfall stations

\begin{tabular}{|c|c|c|c|}
\hline $\begin{array}{c}\text { Number of } \\
\text { station }\end{array}$ & Longitude, $^{\circ}$ & Latitude, $^{\circ}$ & Altitude, $\mathrm{m}$ \\
\hline 1 & 9.68 & 34.20 & 85 \\
\hline 2 & 9.99 & 34.18 & 13 \\
\hline 3 & 9.91 & 34.05 & 52 \\
\hline 4 & 10.04 & 33.96 & 40 \\
\hline 5 & 9.82 & 33.84 & 53 \\
\hline 6 & 10.10 & 33.88 & 4 \\
\hline 7 & 10.11 & 33.86 & 4 \\
\hline 8 & 10.07 & 33.81 & 55 \\
\hline 9 & 9.99 & 33.54 & 441 \\
\hline 10 & 10.28 & 33.62 & 52 \\
\hline
\end{tabular}

Source: own elaboration.

\section{STANDARDIZED PRECIPITATION INDEX}

Drought indices are generally used to characterize drought intensity [GoCIC, TRAJKOVIC 2013]. There are several drought indices available in the literature, such as the standardized precipitation index, standardized precipitation evapotranspiration index, Palmer drought severity index ... etc. [ELLOUZE et al. 2009]. In this work, the standardized precipitation index is considered because it is proved to be more reliable in the characterization and identification of droughts [MOREIRA et al. 2008; PAULO, PEREIRA 2008; TABARI et al. 2012]. Moreover, following the Lincoln Declaration on drought indices, the World Meteorological Organization adopted the standardized precipitation index $(S P I)$ in 2009 as a worldwide instrument to measure meteorological droughts. Indeed, statistical analysis of monthly precipitation based on 
the study of SPI is recognized to be effective in the evaluation of the characteristics of the precipitation deficit [MCKEE et al. 1993]. It reflects the impact of drought on the availability of various water resources. This index is calculated for multiple time scales. It is expressed mathematically as follows:

$$
g(x)=\frac{1}{\beta^{\alpha} \Gamma(\alpha)} \chi^{\alpha-1} e^{-\frac{\chi}{\beta}}
$$

where: $\alpha$ and $\beta$ are the shape and scale parameters of the distribution. They are obtained from the method of least squares, $\Gamma(\alpha)$ is the probabilistic gamma distribution function, $x$ is the height of the monthly precipitation $\chi$.

Computation of the SPI involves fitting the frequency distribution of precipitation in each station to the Gamma distribution of the probability density. The values of parameters of Gamma function are estimated for each station and time scale $(3,12,24,48$ months) and for each month of the year. [ELLOUZE 2010].

This index may be calculated for multiple time scales. Negative SPI values correspond to a precipitation deficit while positive values indicate rainfall excess. HAYES et al. [1999] proposed a classification system to define drought intensities resulting from the SPI value (Tab. 2).

Table 2. Drought severity classification based on SPI values

\begin{tabular}{|c|c|}
\hline$S P I$ value & Class \\
\hline$S P I \geq 2.00$ & extremely wet \\
\hline $1.50 \leq S P I<1.99$ & severely wet \\
\hline $1.00 \leq S P I<1.49$ & moderately wet \\
\hline$-0.99 \leq S P I<0.99$ & near normal \\
\hline$-1.49 \leq S P I<-1.00$ & moderately drought \\
\hline$-1.99 \leq S P I<-1.50$ & severely drought \\
\hline$S P I \leq-2.00$ & extremely drought \\
\hline
\end{tabular}

Source: HAYES et al. [1999], modified.

The SPI of short time scales (for example, 3 and 6 months) describes drought events affecting agricultural practices. In this study, the SPI at a 12-month time scale was selected because it is more suitable for water resources management purposes and more appropriate for identifying the persistence of dry periods [MILANOVIC et al. 2014]. SPI-12 was calculated for each month. It was computed for the month of August based on annual rainfall of the preceding 12 months starting from September to consider an entire hydrologic year. To refine the analysis, we also used the other monthly $S P I$ values in the frequency and duration analysis. The SPI is used to determine the excess and deficit rainfall episodes in Gabes Watershed. Spatial variability of the computed SPI values for the selected extreme rainfall events is then examined by ordinary kriging techniques.

\section{GEOSTATISTICAL TOOLS}

Kriging refers to a surface interpolation technique based on spatially dependent variance, which estimates variable values at desired locations in space using the known sampling values [WEBSTER, OLIVER 2007]. Ordinary kriging is a commonly used interpolation method, generally adopted to model the spatial distribution of a studied variable. In this work, it was used to determine the spatial variability of SPI values for four selected drought periods in Gabes Watershed.

The kriging technique highly depends on the variogram model that defines the spatial structure of the data used. We used four standard variogram models, namely, exponential, Gaussian, Gaussian Bessel, and spherical models in order to fit the experimental variogram, derived based on the observed rainfall data. Fitting of variogram model was performed by Easy krig 3.0 software. The model with the lowest rootmean-square error (RMSE) was chosen as the best fit variogram model. Finally, the adequacy of the adopted standard variogram model was tested by a leaveone-out cross validation procedure.

\section{RESULTS AND DISCUSSION}

\section{RAINFALL ANNUAL VARIABILITY}

The statistical characteristics of the annual precipitation time series during the period 1987-2012 are summarized in Table 3 . The mean annual precipitation varies from 100 to $200 \mathrm{~mm}$. Stations 3 and 5, in the North and the West of study area respectively, have the lowest mean annual precipitation. In general, stations in the South of the basin receive more rainfall than those in the North. Standard deviation of annual rainfall varies between $79 \mathrm{~mm}$ and $129 \mathrm{~mm}$ (for stations 8 and 4 respectively). The average coefficient of variation $(\mathrm{CV})$ is 0.62 , indicating an important interannual variation of rainfall. The highest coefficient of variation of the precipitation values $(80 \%)$ was observed in station 3 while the lowest coefficient of variation $(50 \%)$ was found in stations 8 and 10 located in the South of the watershed. These results clearly show temporal variation patterns of annual rainfall in most stations during the observed period. The maximum annual precipitation $(555 \mathrm{~mm})$ was observed in station 4 in 1995. The minimum precipitation $(5 \mathrm{~mm})$ was observed in 2007 in station 3.

Extreme rainfall events may be attributed to cold fronts, showers and thunderstorms associated with cold air masses from the Mediterranean Sea. Heavy rains occur ahead of cold fronts, particularly when the air is warm and humid. The results also show that an important amount of precipitation falls in mountainous areas and coastal areas near the Mediterranean Sea. 
Table 3. Statistical parameters of annual precipitation time series for the period 1987-2012

\begin{tabular}{|c|c|c|c|c|c|c|c|c|}
\hline $\begin{array}{c}\text { Station } \\
\text { number }\end{array}$ & $\begin{array}{c}\text { Minimum } \\
\text { rainfall } \\
\mathrm{mm}\end{array}$ & $\begin{array}{c}\text { Year of } \\
\text { minimum } \\
\text { rainfall }\end{array}$ & $\begin{array}{c}\text { Mean } \\
\text { rainfall } \\
\mathrm{mm}\end{array}$ & $\begin{array}{c}\text { Maximum } \\
\text { rainfall } \\
\mathrm{mm}\end{array}$ & $\begin{array}{c}\text { Year of } \\
\text { maximum } \\
\text { rainfall }\end{array}$ & $\begin{array}{c}\text { Coefficient } \\
\text { of variation } \\
(\mathrm{CV})\end{array}$ & $\begin{array}{c}\text { Skewness } \\
\text { coefficient }\end{array}$ & $\begin{array}{c}\text { Kurtosis } \\
\text { coefficient }\end{array}$ \\
\hline 1 & 10.0 & 1987 & 144.4 & 361.5 & 1989 & 0.6 & 0.97 & 0.52 \\
\hline 2 & 60.0 & 1996 & 163.0 & 410.0 & 1995 & 0.6 & 1.34 & 1.60 \\
\hline 3 & 4.5 & 2007 & 99.7 & 310.4 & 1989 & 0.8 & 1.27 & 1.67 \\
\hline 4 & 41.5 & 2012 & 174.6 & 554.9 & 1995 & 0.7 & 1.65 & 2.23 \\
\hline 5 & 19.2 & 2000 & 119.5 & 326.0 & 2006 & 0.7 & 1.32 & 0.91 \\
\hline 6 & 26.7 & 2012 & 172.8 & 521.7 & 1995 & 0.6 & 2.00 & 5.87 \\
\hline 7 & 56.6 & 2012 & 184.4 & 551.6 & 1995 & 0.6 & 2.00 & 4.87 \\
\hline 8 & 28.0 & 2012 & 174.4 & 443.5 & 1995 & 0.5 & 1.21 & 1.71 \\
\hline 9 & 29.5 & 2000 & 177.4 & 438.5 & 1995 & 0.6 & 0.81 & 0.35 \\
\hline 10 & 27.5 & 2012 & 197.5 & 352.0 & 2003 & 0.5 & 0.04 & -0.88 \\
\hline
\end{tabular}

Source: own study.

Skewness coefficient values for all stations are positive, indicating that low rainfall happens frequently while high rainfall events occur rarely. For some of the stations, the skewness coefficient is close to zero, implying a normal distribution of rainfall data. Most of the stations have positive kurtosis values. The exception is made for station 10 , which has a negative kurtosis coefficient, indicating a flatter statistical distribution. Station 6 has a kurtosis coefficient greater than 5 , indicating that low rainfall values are more frequent than high rainfall values [AMRUTHA, SHREEDHAR 2014].

According to results in Table 3,50\% of stations have a minimum rainfall observed in 2012; while $50 \%$ of stations have a maximum rainfall observed in 1995.

Figure 2 shows annual rainfall variability in four selected stations, representing different zones of the

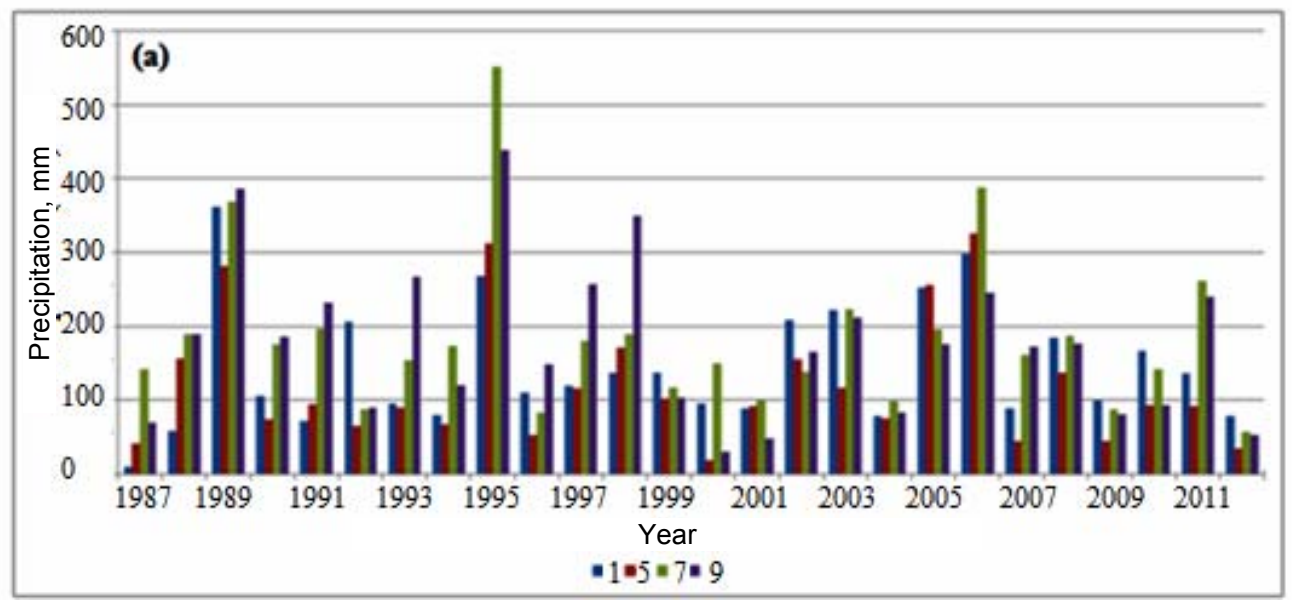

Fig. 2. Annual rainfall variability at four selected representative stations (1987-2012); source: own study

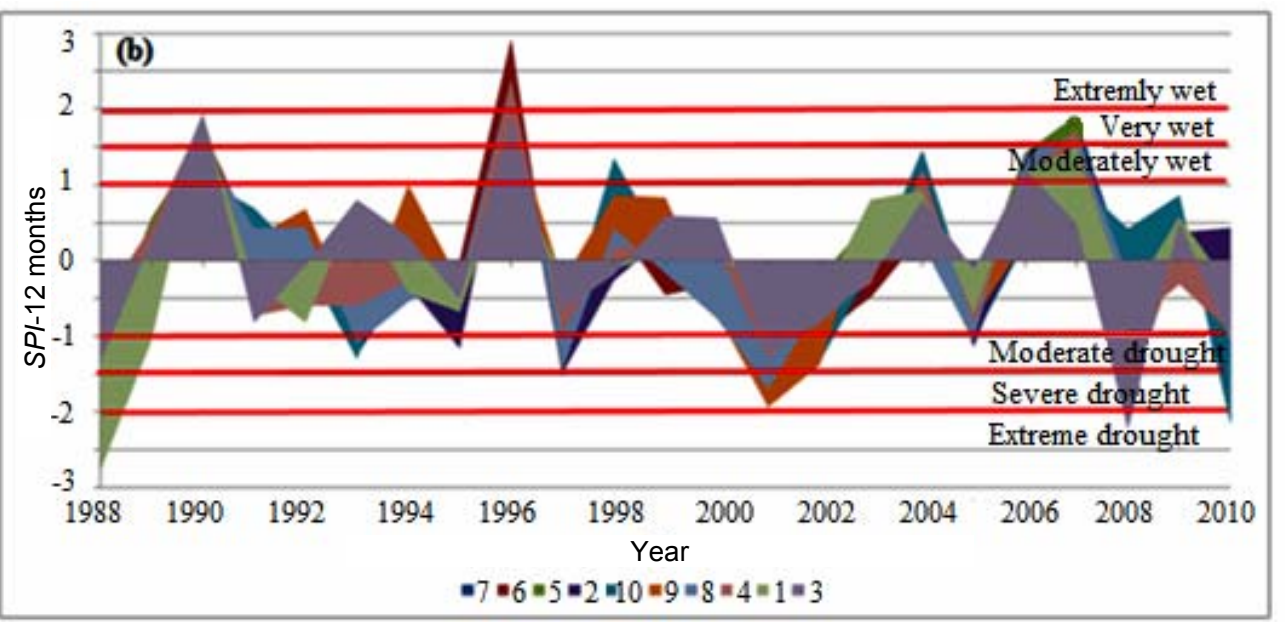

Fig. 3. Temporal variation of SPI-12 for the 10 examined stations; source: own study 
study basin. These are stations 1, 5, 7, and 9, located in the North, the West, the East, and the South of Gabes Watershed. Compared to all other stations, station 9, located in the mountanious region of Matmata, is characterized by a very high altitude. Annual rainfall ranges between $10 \mathrm{~mm}$ in station 1 (1987) and $552 \mathrm{~mm}$ in station 7 (1995). Indeed, rainfall gradients are extremely high in arid areas. The data also show that dry years are more frequent than wet years. Excess years are more frequent, more persistent and more imortant in the East (along the coast) and the south (mountains of Matmata) while the rest of the basin (the North and the West) is rather characterized by more frequent deficit years. The wet years were found to be 1989-1990, 1995-1996, 2006-2007 and 2010-2011 while the dry years or periods were 1987-1988, 1994-1995, 1996-1997, 1999-2002, 2004-2005, 2007-2008, 2009-2010 and 2011-2012.

Because of the irregular rainfall distribution, standardized precipitation index was computed to investigate the excess and deficit rainfall episodes in Gabes Watershed. The SPI data sets used in this study were computed from annual rainfall data.

\section{ANALYSIS OF SPI-12 MONTHS}

Standardized precipitation index was considered to identify hydrological extremes in Gabes Watershed over the study period. Figure 3 displays the temporal variation of SPI-12 values from 1987 to 2012 for the ten examined stations. SPI-12 was calculated for each month. It was computed for the month of August based on annual rainfall of the preceding 12 months starting from September to consider a whole hydrologic year. To refine the analysis, we also used the other monthly SPI values in the frequency and duration analysis.

The results obtained show a heterogeneous distribution of SPI-12 values over the whole basin. Data for all stations indicate alternating periods of deficit and excess of rainfall. Different stations have their own deficit periods, although some years seem exceptionally dry or exceptionally wet in the entire basin. For all the stations considered in this study, the dry sequences were significantly longer than wet sequences. The years characterized by excess rainfall are 1989-1990, 1995-1996 and 2006-2007. The deficit years are 1987-1988, 1996-1997, 2000-2001, 2001-2002, 2007-2008, 2008-2009 and 2009-2010 (Fig. 3). The end of the 1980 s and the years 2000 to 2010 were found to be much drier than other decades. Therefore, deficit episodes were most frequent than the wet episodes over recent decades. Stations most affected by rainfall decrease are located either in the north (Station 3) or the south of the study basin (Station 9). Moderate drought sequences are observed in the east of the watershed along the coast.

The analysis of the frequency and duration of the observed sequences of drought in Gabes Watershed is realized. The characteristics of droughts at the 12 month time scale are summarized in Table 4 . These include the frequency of dry spells, the mean duration of dry months, the percentage of time under drought, and the extreme value of the SPI with the corresponding date of occurrence.

The most severe drought period for seven stations occurred in 2001. Regarding the remaining three stations, the most severe drought year was 2008 for stations 3 and 4, while station 1 had the lowest SPI-12 value -3.13 in February 1988. The maximum number of dry sequences (SPI-12) was observed in station 4 , where 13 dry events were observed with a mean duration of one month (2.08). The most remarkable period is 8 months (May to December 2001) with an SPI mean value of -2.08 and extreme $S P I$ of -2.16 for the month of December 2008 (Tab. 4). The sum of dry months ranges between 27 and 49, for stations 4 and 10 respectively. Station 10 , located in the south-east of the study basin, shows drought conditions corresponding to $2.65 \%$ of the total time of drought, with a frequency of 7 sequences corresponding to the highest mean duration ( 7 months). Three major events were detected. The first event, with a mean duration of 14 months, extends from October 2000 to November 2001. The second event occurred over the period between January and November 2010. The third event is from January to September 2002, with a mean duration of 9 months.

Table 4. Observed sequences of drought at the 12 month time scale (SPI-12months) during the period 1987-2012

\begin{tabular}{|c|c|c|c|c|c|}
\hline $\begin{array}{l}\text { Station } \\
\text { number }\end{array}$ & $\begin{array}{c}\text { Number } \\
\text { of dry sequences }\end{array}$ & Sum of dry months & $\begin{array}{l}\text { Mean duration } \\
\text { month }\end{array}$ & $\begin{array}{l}\text { Percentage of time } \\
\text { under drought }\end{array}$ & $\begin{array}{l}\text { Extreme value } S P I-12 \\
\text { (date of occurrence) }\end{array}$ \\
\hline 1 & 5 & 30 & 6.00 & 2.17 & -3.13 (Feb. 1988) \\
\hline 2 & 11 & 42 & 3.82 & 1.45 & -2.02 (Oct. 2001) \\
\hline 3 & 10 & 41 & 4.10 & 1.55 & -2.84 (Dec. 2008) \\
\hline 4 & 13 & 27 & 2.08 & 0.79 & -2.16 (Dec. 2008) \\
\hline 5 & 11 & 47 & 4.27 & 1.62 & $\begin{array}{c}-1.97 \text { (Jun. 2001) } \\
\text { (Jul. 2001) }\end{array}$ \\
\hline 6 & 9 & 36 & 4.00 & 1.52 & -1.99 (Nov. 2001) \\
\hline 7 & 12 & 46 & 3.83 & 1.45 & -1.92 (Nov. 2001) \\
\hline 8 & 11 & 43 & 3.91 & 1.48 & -1.84 (Sep. 2001) \\
\hline 9 & 8 & 47 & 5.88 & 2.23 & -2.55 (Nov. 2001) \\
\hline 10 & 7 & 49 & 7.00 & 2.65 & -2.62 (Feb. 2001) \\
\hline
\end{tabular}

Source: own study. 
Time percentage under drought varies between $0.79 \%$ and $2.65 \%$ in station 4 and 10 respectively. The most extreme event was observed in station 1 with a mean $S P I-1.36$ and an extreme $S P I$ of -3.13 in February 1988 (Tab. 4). Through 12 SPI-term, Station 1, located in the North-West of the basin, shows a decrease in dry episodes to 5 , with an important increase in the average estimated duration to 6 months.

Deficit periods were more frequent than the wet periods in recent decades. Moreover, compared to wet sequences, drought periods extend over longer periods. The excess years with varying intensities represent nearly $14 \%$, while the deficit years are around $16 \%$. The normal average years represent nearly $70 \%$. This is very close to theoretical results. The threshold value of SPI -1.0 corresponds to the probability of 0.16 . The differences between the obtained values and the value of 0.16 for certain periods result from poor machining precipitation probability distribution to a normal distribution. Usually the cause is also relatively short measurement series. If the fitting of the probability distribution would be exact and the series long enough the frequencies would be similar in each location.

\section{Variographic analysis}

Four of the most severe drought events were selected to examine their spatial distribution using variographic analysis and ordinary kriging techniques.
These drought sequences occurred in August 1988, 2001, 2008, and 2010. First, experimental variograms were computed and then different variographic models were tested to select the best fit model. The exponential model resulted in the lowest RMSE value, and was therefore selected as the best-fit model. It was used to map the 12 month SPI in Gabes Watershed. This exercise resulted in selecting the exponential distribution model, known to best represent rainfall variability in arid regions, as was shown by FEKI [2010] among others.

\section{SPI maps}

Mean monthly SPI during the four study periods varied from -2.79 to 0.43 . It indicates the spatial heterogeneity of the phenomenon of drought especially in the study area. This important SPI variability was higher and clearly shows the extreme drought intensity in the last decade. It can be related to the annual rainfall deficit that began in the early 1970s. Given the fact that the potential evaporation (vary from 1500 $\mathrm{mm}$ to $2000 \mathrm{~mm}$ ) is much higher than the actual moisture supply in the semi-arid region [ZHANG, LIN 1992] even a moderate increase in the precipitation amount cannot mitigate the drought stress significantly.

SPI maps were developed, for the four identified drought events, to characterize their particular rainfall spatial variability (Fig. 4). Figure 4a (August 1988) shows normal to moderate drought condition all over
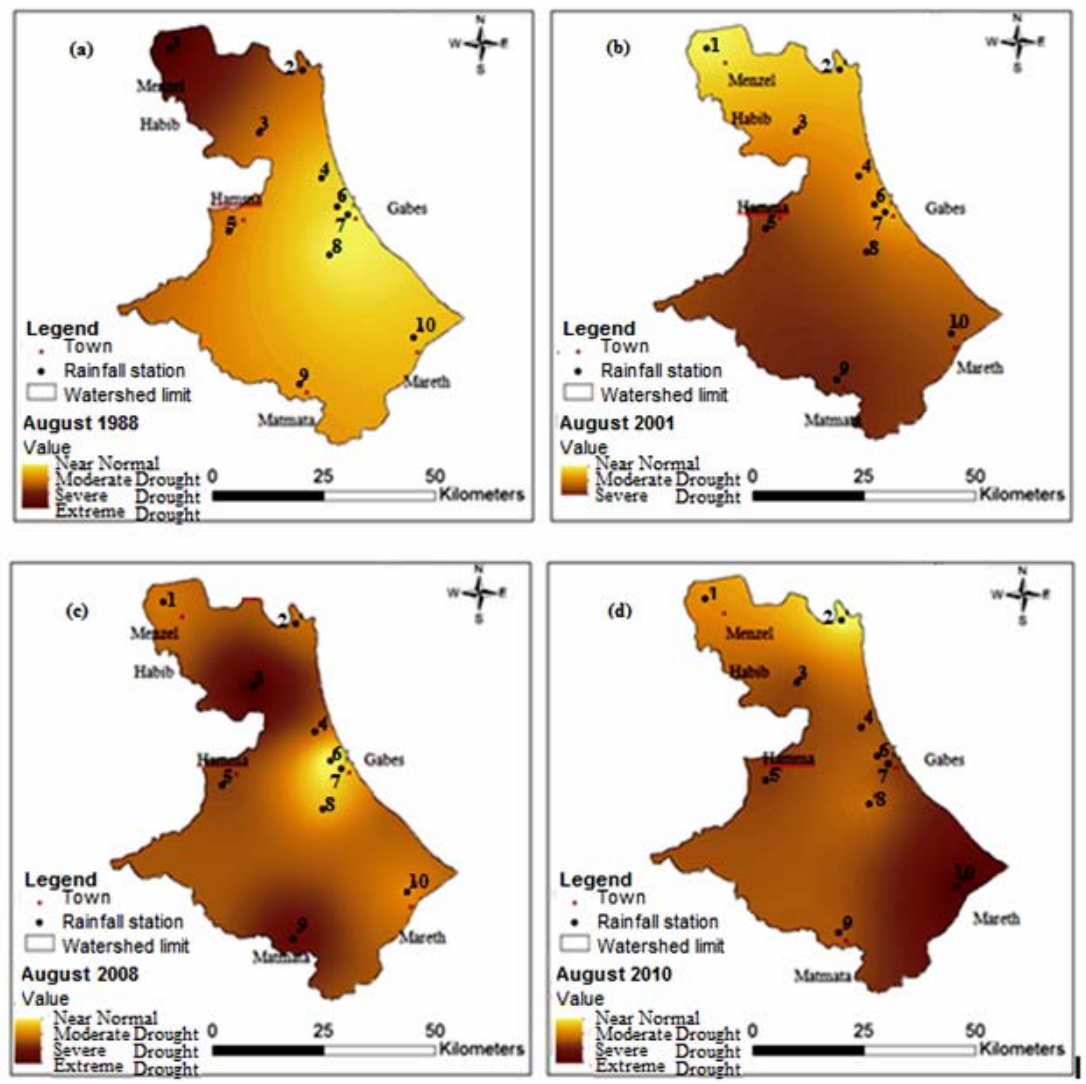

Fig. 4. SPI spatial distribution in Gabes Watershed for the selected drought events: a) August 1988, b) August 2001, c) August 2008, d) August 2010; source: own study 
the study basin, except for the extreme North, where rather extreme drought is encountered. Figure $4 \mathrm{~b}$ (August 2001) also shows that the extreme North behaves differently, compared to the rest of the basin. However, unlike the event of 1988, the extreme North is characterized by normal to moderate drought condition while severe drought is encountered elsewhere. For the event of August 2008 (Fig. 4c), normal conditions were observed in the South and along the coast. In this event, moderate drought (station 5), severe drought (station 9) and extreme drought (station 3) were also observed.

Figure 4d (August 2010) presents drought patterns similar to those of the event of August 2001 (Fig. 4b), with relatively extreme drought in the South and along coast and normal to moderate drought condition elsewhere.

The medium term analysis (SPI-12 months) showed that moderate droughts in most of the watershed of Gabes are characterized by higher probabilities, compared to severe and/or extreme events. This result is consistent with the results of other studies dealing with time and space variability of precipitation in Gabes watershed [ELLOUZE 2009; FEKI et al. 2012].

According to previous studies [ElLOUZE et al. 2009], the change in SPI is closely connected to the changes in the annual rainfall. In Gabes watershed, the rainfall gradient increases from the North to the South. Rainfall also increases, from the West (in the continent) to the East (littoral). The earlier studies support this finding. On the other hand, Gabes is mainly a plane region, where rainfall variability is more governed by the Mediterranean Sea proximity. Rainfall increases continuously from the west (continent) to the east (coast line), implying an important effect of longitude and see proximity of the Sea. Therefore, the drought will be more pronounced in the western and northern regions compared to the coastal and southern zones (Matmata Mountains). The obtained result of SPI obtained through kriging maps confirmed these results. It is also important to note the influence of the Mediterranean Sea conditions on annual rainfall distribution. North Africa would be particularly affected by droughts that would be more frequent, more intense and longer-lasting [EL-RAEY 2009].

\section{CONCLUSIONS}

This study investigated rainfall variability in Southern Tunisia by analyzing monthly and annual precipitation data collected from ten synoptic stations in Gabes Watershed over the period extending from 1987 to 2012. The standardized precipitation index $(S P I)$ analysis was applied to monthly series of precipitations. In the medium term (SPI-12 months), this index allows to define the deficit or excess of rainfall. In this research, the most remarkable droughts by duration or geographical extent were in the late 1980s and 2000 for the majority of the stations. The comparison of the different data sets showed similar climatic conditions and common dry sequences with the same frequency, duration and severity. These dry periods were confirmed by break detection of statistical tests (Mann-Kendall) and were also found in previous studies. The deficit periods are more frequent than wet periods. Excess years with varying intensities represent nearly $14 \%$, while the deficit years are around $16 \%$. The analysis of $S P I-12$ results may be useful for better planning and effective management of water resources.

This study also investigated the spatial variability of drought in Gabes Watershed. This spatial variability was analyzed by geostatistical tools via mapping the SPI-12 months for four of the most severe drought events: August 1988, August 2001, August 2008 and August 2010. Several semi-variograms were tested. The exponential model resulted in the lowest RMSE value, and was therefore selected as the best-fit model. It was used to map the 12 month SPI in Gabes watershed. Ordinary kriging was used to develop interpolated surface maps. The results obtained showed that the severity of drought was important in the western and northern regions, while the coast and the southern regions were characterized by mild droughts, showing thereby the effects of altitude and the Mediterranean Sea.

\section{ACKNOWLEDGMENTS}

This study was performed within the Research Unit of Applied Hydrosciences of Gabes, Tunisia. Daily rainfall data were provided by the Regional Commissariat for Agricultural Development (CRDA) of Gabes, Tunisia. The authors also would like to thank the editors and the anonymous reviewers for their constructive comments, which improved the quality of this paper.

\section{REFERENCES}

AmRUtha RANi H.R., SHREEDHAR R. 2014. Study of rainfall trends and variability for Belgaum. International Journal of Research in Engineering and Technology. Vol. 3. Iss. 6 p. 148-155.

BĄK B., ŁABĘDZKI L. 2014. Prediction of precipitation deficit and excess in Bydgoszcz Region in view of predicted climate change. Journal of Water and Land Development. No. 23 p. 11-19.

Delfiner P., Delhomme J.P. 1975. Optimum interpolation by kriging. In: Display and analysis of spatial data. Eds J.C. Davis, M. J. McCullagh. London. John Wiley and Sons p. 96-114.

EL-RAEY M. 2009. Impact of climate change: Vulnerability and adaptation of coastal areas. Report of the Arab Forum for Environment and Development. Eds M.K. Tolba, N.W. Saab. Beirut, Lebanon. AFED p. 4762.

ELlouZE M. 2010. Development of a triangular modelfor the generation of synthetic hyetographs and spatiotemporal characterization of drought in central and southern Tunisia. PhD Thesis. Tunis, Tunisia. Faculty of Science Sfax pp. 182. 
Ellouze M., AzRi C., ABIDA H. 2009. Spatial variability of monthly and annual rainfall data over Southern Tunisia. Journal of Atmospheric Research. Vol. 93. Iss. 4 p. 832-839.

FEKI H. 2010. Regionalised optimization weather stations network in Tunisia geostatistical interpolation-step monthly and annual time. PhD. Thesis. Tunis, Tunisia. National Institute of Agronomy pp. 188.

FeKi H., Slimani M., CudENNEC C. 2012. Incorporating elevation in rainfall interpolation in Tunisia using geostatistical methods. Hydrological Sciences Journal. Vol. 57. Iss. 7 p. 1294-1314.

GiBBS W.J., MAHER J.V. 1967. Rainfall deciles as drought indicators. Melbourne. Bureau of Meteorology Bulletin. Vol. 48 pp. 84.

GILBERT R.O. 1987. Statistical methods for environmental pollution monitoring. New York. Van Nostrand Reinhold Company Inc. ISBN 0-442-23050-8 pp. 320.

Gocic M., TRAJKOVIC S. 2013. Analysis of precipitation and drought data in Serbia over the period 1980-2010. Journal of Hydrology. Vol. 494 p. 32-42.

Gong D.Y., SHI P.J., WANG J.A. 2004. Daily precipitation changes in the semi-arid region over northern China. Journal of Arid Environments. Vol. 59. Iss. 4 p. 771784.

Hall A.J., Barclay P.A. 1975. Methods of determining areal rainfall from observed data. In: Prediction in Catchment Hydrology. Eds T.G. Chapman, F.X. Dunin. Canberra. Australian Academy of Science p. 47-57.

Hayes M.J., Svoboda M.D., Wilhite D.A., VANYARKho O.V. 1999. Monitoring the 1996 drought using the standardized precipitation index. Bulletin of the American Meteorological Society. Vol. 80. Iss. 3 p. 429-438.

IPCC 2007. Climate change 2007: The physical science basis. In: Contribution of Working Group I to the Fourth Assessment Report of the Intergovernmental Panel on Climate Change. Eds. S. Solomon, D. Qin, M. Manning, Z. Chen, M. Marquis, K.B. Averyt, M. Tignor, H.L. Miller. Cambridge, United Kingdom, New York, NY, USA. Cambridge University Press pp. 996.

KENDALL M.G. 1975. Rank correlation methods. 4th ed. London. Charles Griffin pp. 202.

ŁABĘDZKI L. 2016. Actions and measures for mitigation drought and water scarcity in agriculture. Journal of Water and Land Development. No. 29 p. 3-10.

MANN H.B. 1945. Non-parametric tests against trend. Econometrica. Vol. 13 p. 163-171.
MCKee T., Doesken N., Kleist J. 1993. The relationship of drought frequency and duration to time scales. In: Proceeding of the Eighth Conference on Applied Climatology, Anaheim, California. USA, 17-22 January 1993.

Milanovic M., Gocic M., Trajkovic S. 2014. Analysis of meteorogical and agricultural droughts in Serbia. Facta Universitatis. Ser. Architecture and Civil Engineering. Vol. 12. Iss. 3 p. 253-264.

ModARRES R., SILVA V.P.R. 2007. Rainfall trends in arid and semi-arid regions of Iran. Journal of Arid Environments. Vol. 70. Iss. 2 p. 344-355.

Moreira E.E., Coelho C.A., Paulo A.A., Pereira L.S., MEXIA J.T. 2008. SPI-based drought category prediction using log-linear models. Journal of Hydrology. Vol. 354 (1-4) p. 116-130.

PALMER W.C. 1965. Meteorological drought. Research Paper. Vol. 45 p. 58. Washington, D.C. U.S. Department of Commerce Weather Bureau [NOAA Library and Information Services Division, Washington, D.C. 20852]

PALMER W.C. 1968. Keeping track of crop moisture conditions nationwide: The new crop moisture index. Weatherwise. Vol. 21 p. 156-161.

Paulo A.A., Pereira L.S. 2008. Stochastic prediction of drought class transitions. Water Resources Manage. Vol. 22. Iss. 9 p. 1277-1296.

Shafer B.A., DeZMAn L.E. 1982. Development of a surface water supply index to assess the severity of drought conditions in snow-pack runoff areas. Proceedings of the Western Snow Conference, Reno, NV, Colorado State University. April 19-23 p. 164-175.

SiLVA V.P.R. 2004. On climate variability in Northeast of Brazil. Journal of Arid Environments. Vol. 58. Iss. 4 p. 575-596.

Tabari H., Abghri H., Hosseinzadeh Talaee P. 2012. Temporal trends and spatial characteristics of drought and rainfall in arid and semiarid regions of Iran. Hydrological Processes. Vol. 26. Iss. 22 p. 3351-3361.

Webster R., Oliver M.A. 2007. Geostatistics for environmental scientists. 2nd ed. Chichester, UK. John Wiley and Sons. ISBN 978-0-470-02858-2 pp. 330.

Willeke G., Hosking J.R.M., Wallis J.R., GutTMAN N.B. 1994. The national drought atlas. Institute for Water Resources Report 94-NDS-4, U.S. Army Corps of Engineers pp. 587.

ZhANG J.C., Lin Z.G. 1992. Climate of China. New York. Wiley and Shanghai Scientific and Technical Publishers. ISBN 0471519138 pp. 376.

\section{Sabrine JEMAI, Manel ELLOUZE, Belgacem AGOUBI, Habib ABIDA}

\section{Intensywność i przestrzenna zmienność suszy w zlewni Gabes w południowo-wschodniej Tunezji}

\section{STRESZCZENIE}

Analizowano serie miesięcznych i rocznych opadów notowane w zlewni Gabes w południowo-wschodniej Tunezji. W badaniach wykorzystano wartości standaryzowanego wskaźnika opadu (SPI) obliczonego dla 10 stacji opadowych w latach 1987-2012, co odpowiada okresowi obserwacji równemu 25 latom hydrologicznym (od września do sierpnia). Uzyskane wyniki dowodzą znacznej zmienności wartości SPI. Zmienność w czasie umożliwiła zdefiniowanie okresów nadmiaru i deficytu opadów, które odpowiadają okresom mokrym i suchym. Mokrymi okresami okazały się lata 1989-1990, 1995-1996 i 2006-2007, podczas gdy susze przypadały na lata 1987-1988, 1996-1997, 2000-2001, 2001-2002, 2007-2008, 2008-2009 i 2009-2010. Wskazuje to jasno na naprzemienność okresów mokrych i suchych z przewagą tych ostatnich w czasie objętym badaniami. Rzeczywi- 
ście obserwowano tendencję do zmniejszania opadów i do występowania sekwencji okresów suszy. Przestrzenną zmienność suszy w zlewni Gabes badano za pomocą geostatystycznej analizy SPI, ponieważ rozmieszczenie susz i opadów zmienia się wraz z szerokością i długością geograficzną i zależy od topografii oraz odległości od Morza Śródziemnego. Uzyskane wyniki świadczą, że susze były intensywniejsze na zachód i północ od zlewni Gabes niż na obszarach przybrzeżnych i południowych. Wskaźnik SPI dowodzi, że umiarkowane susze są częstsze niż susze intensywne i ekstremalne w większej części zlewni.

Słowa kluczowe: analiza trendu, geostatystyka, opady, standaryzowany wskaźnik opadów, susza, Tunezja 